\title{
Economic evaluation of spotted knapweed [Centaurea macu- losa] control using picloram
}

\author{
DUANE GRIFFITH AND JOHN R. LACEY
}

\begin{abstract}
Spotted knapweed is the most serious renge weed problem in western Montana. Although picloram is often used to control knapweed, the economic feasibility of the practice has not been evaluated. We developed a model to economically evaluate spotted knapweed control on rangeland. Model functions describing the dynamics of the plant community preceding and following treatment were derived from field observations in western Montana. Economic returns per management unit were calculated for 3 scenarios: (1) no treatment, (2) containment, and (3) eradication of spotted knapweed. After tax costs and benefits of treatments were analyzed for a 20-year period and discounted to the present. An economic loss in current dollars of $\mathbf{\$ 2 . 3 8 / h a}$ was incurred under the no treatment strategy when $25 \%$ of the management unit was initially infested with spotted knapweed and the weed was spreading to new acres and replacing desirable forage. After-tax present value of added AUMs in the eradication strategy was greater than the after-tax present value of added costs, $\$ 3.41 /$ ha and $\$ 1.99 /$ ha, respectively. As site productivity, value of an AUM, and rate of knapweed spread to new acres increased, economic returns increased relative to treatment costs. In contrast, herbicide treatment became less cost-effective as knapweed utilization by livestock increased. Thus, economic feasibility of spotted knapweed control varied with economic and biologic conditions.
\end{abstract}

Key Words: sensitivity analysis, picloram, capital investment analysis, economic feasibility, eradication, rangeland

Spotted knapweed (Centaurea maculosa) threatens range productivity in western Montana (Lacey et al. 1986). The introduced weed has invaded about 1.8 million hectares of range and pasture in Montana (Lacey 1987). Carrying capacity has been reduced to virtually zero on some sites (Bawtree and McLean 1977), and the loss of soil and water resources is a concern (Lacey et al. 1989). Spotted knapweed has the potential to reduce the annual gross revenue of Montana ranchers by $\$ 155$ million (Bucher 1984).

Investment decisions regarding knapweed control are complex. A herbicide treatment, picloram (22K) at $0.28 \mathrm{~kg} / \mathrm{ha}$ active ingredient (AI), usually kills all established plants. The herbicide residual prevents seedling establishment for 2 to 4 years (Lacey et al. 1986). Initial treatment cost is approximately $\$ 34 /$ ha. Grass response varies with site potential and degree of knapweed control. Picloram often has to be reapplied because some knapweed seed is still viable after 7 years in the soil (Davis and Fay 1989). The effective life of the treatment varies with species and vigor of the grass community, amount of bare ground, organic matter, other soil characteristics, and subsequent management. These complexities have discouraged economic feasibility studies (Bucher 1984, Jenson 1984).

The objective of this study was to evaluate the economic feasibility of controlling spotted knapweed on rangeland. A model was developed and used to compare no action or no treatment, con-

Authors are assistant professor, Agricultural Economics and Economics Department, Montana State University; and extension range management specialist, Animal and Range Sciences Department, Montana State University.

Research was funded in part by DOW Chemical Company. The use of trade names in this publication does not imply endorsement by Montana State University of the products named nor criticism of similar ones not mentioned.

Manuscript accepted 12 April 1990. tainment to prevent knapweed's spread to uninfested areas, and eradication strategies. Sensitivity analyses were used to assess a range of environmental and economic factors. Results should aid weed control decisions in the Northern Intermountain region.

\section{Methods and Procedures}

Herbage production was modeled for 3 distinct spotted knapweed control strategies: (1) no action or no treatment, (2) containment to prevent its spread to uninfested areas, and (3) eradication. A 20-year time frame was used. Herbage production was limited to the biological potential of range sites.

Herbage and forage production were evaluated per management unit, a block of land managed under a single weed plan. Management units may consist of a few acres within a pasture, a pasture, a ranch, or several ranches. Herbage includes all grasses, forbs, and shrubs. Herbage is less restrictive than forage, which only includes material that is acceptable and available to grazing animals. Forage in a spotted knapweed-infested management unit includes all usable species including knapweed, within infested and uninfested areas.

\section{Rate of Knapweed Spread and Production}

Number of hectares invaded annually by spotted knapweed depended on the size of initial infestation and the rate of spread (Eq. 1; Table 1). Knapweed herbage and forage production are influenced by rate of spread, and increases in density subsequent to initial infestation and utilization by livestock (Eqs. 2, 3).

\section{Herbage and Forage Production of Other Species}

Production of desirable species included growth on knapweedinfested and uninfested areas of the management unit (Eqs. 4-6; Table 1). Production declined as knapweed density increased on infested sites, and as knapweed spread into new areas.

The rate of spotted knapweed spread to uninfested hectares was a variable in the model. If acreage records are accurate, spotted knapweed has spread in Montana at the rate of $27 \%$ per year since 1920 (Lacey 1983). Total herbage and forage included production of desirable species and knapweed (Eqs. 6, 7).

Herbage response to picloram treatment has been evaluated on spotted knapweed-infected sites in western Montana (Chicoine 1984, Lacey 1985, Bedunah 1989). Their data were used for estimating first-year herbage response. Knapweed production on a site prior to treatment explained $94 \%$ of the variation in post treatment grass response.

$$
\begin{aligned}
\mathrm{HR}_{\mathrm{f}}= & +0.624(\mathrm{~kg} / \mathrm{ha} \text { of spotted knapweed }) \\
& (P<0.0001)
\end{aligned}
$$

where $H_{R_{f}}$ was the change in grass production occurring from the time of herbicide application through the first growing season. For example, if grass and knapweed averaged 100 and $800 \mathrm{~kg} / \mathrm{ha}$ prior to treatment, respectively, total grass production during the first growing season was pre-treatment grass, $100 \mathrm{~kg} / \mathrm{ha}$, plus post-treatment grass, $.624 \times 800 \mathrm{~kg} / \mathrm{ha}$, or $599 \mathrm{~kg} / \mathrm{ha}$. An additional $30 \%$ of the difference between first year response on treated areas and average production on uninfested areas was assumed for year 2 . For example, $[(900-599) \times .30]$ or $90 \mathrm{~kg} / \mathrm{ha}$ of additional 
Table 1. Equations used to estimate rate of spotted knapweed spread, spotted knapweed production, production of other species, and economics of spotted knapweed control."

Rate of knapweed spread

$M A_{y}=\left(A^{*}(1+S)^{Y} \leq A M\right)-\left(I A(1+S)^{y-1} \leq A M\right)$

Knapweed production

$$
\begin{aligned}
& K I_{y}=\left(I^{*}(1+I)^{Y} \leq M K\right) \\
& K U_{y}=\left(\left(I A * K I_{y}+\sum_{y=0}^{20} M A_{y} * K M_{y}\right) * P_{k}\right) \div A M
\end{aligned}
$$

Herbage and forage production of other species

$$
\begin{aligned}
& \mathrm{FU}_{\mathrm{y}}=\left(\left(\mathrm{IA} * \mathrm{FI}_{\mathbf{y}}+\sum_{\mathrm{y}=0}^{20} \mathrm{MA}_{\mathrm{y}} * \mathrm{FM}_{\mathrm{y}}\right) * \mathrm{P}_{\mathrm{f}}\right) \div \mathrm{AM} \\
& \mathrm{UU}_{\mathrm{y}}=\left(\left(\mathrm{AM}-\left(\mathrm{IA} *(1+\mathrm{S})^{\mathrm{y}} \leq \mathrm{AM}\right)\right) * \mathrm{AP} * \mathrm{P}_{\mathrm{f}}\right) \div \mathrm{AM} \\
& \mathrm{TU}_{\mathbf{y}}=\mathrm{KU}_{\mathrm{y}}+\mathrm{FU}_{\mathrm{y}}+\mathrm{UU}_{\mathrm{y}}
\end{aligned}
$$

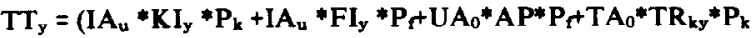

$$
\begin{aligned}
& \left.+\mathrm{TA}_{0}{ }^{*} \mathrm{TR}_{\mathrm{hy}}{ }^{*} \mathbf{P}_{\mathrm{f}}\right) \div \mathrm{AM} \\
& \left.I_{y}=\left(T T_{y}+\left(T T_{y-1} *(1+H)^{y}\right)-T T_{y-1}\right)\right) \leq\left(M M^{*} P_{f}\right)
\end{aligned}
$$

Economic

$$
\begin{aligned}
& P V_{L}=\sum_{y=0}^{20}\left(\left(\mathrm{TU}_{0}-\mathrm{TU}_{\mathrm{y}}\right) \div \mathrm{LB}_{\mathrm{aum}} * \mathrm{ATV}_{\mathrm{aum}}\right) \\
& P V_{c}=\sum_{y=0}^{20}\left(\left(C A_{0}^{*}(1+i)^{y_{*}^{*}} T A_{y}\right)^{*}(1-M T R)^{*} D_{y}\right) \div A M \\
& \mathrm{PV}_{\mathrm{b}}=\sum_{\mathrm{y}=0}^{20}\left(\left(\left(\mathrm{TT}_{\mathrm{y}}-\mathrm{TU}_{\mathrm{y}}\right) \div \mathrm{LB}_{\mathrm{aum}}\right)^{*}\left(\left(\mathrm{~V}_{\mathrm{O}}^{*}(1+\mathrm{i})^{y}\right)\right)^{*}(1-\mathrm{MTR})^{*} \mathrm{D}_{\mathrm{y}}\right) \\
& \begin{array}{ll}
\hline \text { AM } & =\text { Management unit size (ha), } \\
\text { AP } & =\text { Herbage produced on uninfested area }(\mathrm{kg} / \mathrm{ha}) \\
\text { ATV } & =\text { Inflated, tax adjusted, discounted value of an }
\end{array} \\
& \text { ATV } \text { aum = Inflated, tax adjusted, discounted value of an AUM (adjusts future } \\
& \text { benefits lost to present dollars) } \\
& \begin{array}{ll}
\mathrm{CA}_{0} & =\text { Treatment costs/ha during initial year of the analysis, year } 0 \\
\mathrm{D}_{y} & =\text { Tax adjusted discount factor for year } \mathrm{y} \text { of the analysis (adjusts }
\end{array} \\
& \text { future cost to the present) } \\
& \begin{array}{ll}
\mathrm{FI}_{\mathrm{y}} & =\text { Desirable herbage } \mathrm{kg} / \mathrm{ha} \text { in year } \mathrm{y} \text { on infested areas that were } \\
\mathrm{FM}_{\mathrm{y}} & =\text { Deseated } \\
\text { unirable herbage } \mathrm{kg} / \mathrm{ha} \text { in year } \mathrm{y} \text { on marginal area infested }
\end{array} \\
& \begin{array}{ll}
\mathrm{FI}_{\mathrm{y}} & =\text { Desirable herbage } \mathrm{kg} / \mathrm{ha} \text { in year } \mathrm{y} \text { on infested areas that wer } \\
\mathrm{FM}_{\mathrm{y}} & =\text { Desirable }
\end{array} \\
& \begin{array}{ll}
\mathrm{FM}_{\mathbf{y}} & =\text { Desirable herbage } \mathrm{kg} / \mathrm{ha} \text { in year } \mathrm{y} \text { on marginal area infested } \\
\mathrm{FU}_{y} & =\text { Non-knapweed forage available }(\mathrm{kg} / \mathrm{ha}) \text { in year y from desirable }
\end{array} \\
& \text { grasses and other herbage } \\
& =\text { Annual rate of succession under improved management } \\
& \begin{array}{l}
=\text { Expected inflation rate } \\
=\text { Annual rate of increase in knapweed density on infested areas }
\end{array} \\
& \begin{array}{l}
=\text { Annual rate of increase in knapweed density on } \\
=\text { Size (ha) knapweed infestation in initial year }
\end{array} \\
& \text { = Area (ha) of management unit initially infested but untreated under } \\
& \text { a containment strategy } \\
& =\mathrm{Knapweed}(\mathrm{kg} / \mathrm{ha}) \text { on infested area during the initial year } \\
& =\text { Total forage }(\mathrm{kg} / \mathrm{ha}) \text { in year y assuming treatment and improved } \\
& \text { management } \\
& =\mathbf{K n a p w e e d}(\mathrm{kg} / \mathrm{ha}) \text { in year } \mathrm{y} \text { on the initially infested but untreated } \\
& \text { areas } \\
& =\text { Knapweed }(\mathbf{k g} / \mathrm{ha}) \text { on marginal areas during year y (newly infested } \\
& \text { in year } \mathrm{y}) \\
& \text { = Knapweed forage }(\mathrm{kg} / \mathrm{ha}) \text { in year } \mathrm{y} \\
& =\text { Forage (kg) required for one AUM. } \\
& \text { = Marginal ha, new ha, infested in year y }
\end{aligned}
$$

grass would bring total desirable grasses to $689 \mathrm{~kg} / \mathrm{ha}$. In year 3, production was assumed to be equal to total herbage production on uninfested hectares prior to picloram treatment. Herbage production was constant from years 3 through 20 , assuming that picloram was reapplied to prevent knapweed reestablishment.

Our model allows analysis of improved grazing management in conjunction with herbicide treatment (Eq. 8). However, analyses are not reported here because of the difficulty in separating treatment effects from improved management.

Daily forage requirements of ruminants average about $2 \%$ of their body weight on a dry weight basis ( $K$. Havstad, pers. comm.). Thus, an animal unit or a 454-kg animal requires from 9-10 kg daily, or $299 \mathrm{~kg}$ per month. This does not include forage disappearance, trampling, and other losses. The added forage available after knapweed treatment was divided by $299 \mathrm{~kg}$ to determine additional AUMs available for each year of the analysis. Forage required per animal unit is a model variable.

\section{Economics}

Spotted knapweed control requires a capital investment. Expenses may be concentrated during the initial period of an analysis or be spread throughout the life of the project. Net annual returns are often received over the life of the project.

Our model differs from Ethridge et al.'s $(1984,1987 \mathrm{a}$, and 1987b) capital investment analyses in that forage, not livestock, was the end product. Thus, our approach eliminated the use of livestock enterprise budgets. Although we assume that individual livestock performance was not affected by the presence of knapweed, carrying capacity was reduced by the plant.

Present value analysis was used to evaiuate the economic potential of spotted knapweed control (Table 1, Eqs. 9-11). Investments are economically feasible when the discounted stream of after-tax benefits are greater than the discounted stream of after-tax costs. Current treatments costs and benefits were adjusted annually during the analysis for inflation and taxes.

Taxes were a variable in our model. Tax effects cancel out of the model when the timing and amount of the costs of treatment equal the timing and amount of the benefits. Economic outcomes are influenced by taxes whenever the flow of costs and benefits are unequal.

We used the model to compare the no action, containment and eradication strategies on a 405-ha management unit. Economic assumptions included: cost of treatment $=\$ 34 /$ ha, $A U M=\$ 10$, nominal interest rate $=12 \%$, inflation rate $=7 \%$, and marginal tax rate $=15 \%$. Biological assumptions include: initial infestation of spotted knapweed $=25 \%$ of management unit, knapweed utilization $=20 \%$, utilization of desirable forage $=40 \%, A U M=299 \mathrm{~kg}$, annual rate of forage displacement by knapweed $=15 \%$, annual rate of knapweed spread to new areas $=10 \%$, and grazing management programs following herbicide treatment were not changed,

Table 2. Herbicide treatment by year to control spotted knapweed on high- and low-producing sites as used in the sensitivity analysis 1.

\begin{tabular}{ccc}
\hline & \multicolumn{2}{c}{$\%$ Hectares Treated by Year } \\
\cline { 2 - 3 } Year & High-producing site & Low-producing site \\
\hline 1 & 100 & 100 \\
3 & 60 & 80 \\
6 & 30 & 60 \\
9 & 15 & 40 \\
12 & 5 & 20 \\
15 & 5 & 10 \\
18 & 5 & 10 \\
\hline
\end{tabular}

In a containment strategy $20 \%$ of the infested hectare was treated in the first year, and $10 \%$ each following year. Retreatment schedule based on recommendations of weed scientists and land managers in Western Montana. 
Table 3. Summary of no spotted knapweed treatment given the specified parameters, on a high-producing site.

\begin{tabular}{|c|c|c|c|c|c|c|c|}
\hline $\begin{array}{l}\text { Year(s) } \\
\text { Treated }\end{array}$ & $\begin{array}{l}\text { Number } \\
\text { Infested } \\
\text { Hectares }\end{array}$ & $\begin{array}{c}\text { Average } \\
\text { Knapweed } \\
\text { Production } \\
\text { (kg/ha) }\end{array}$ & $\begin{array}{c}\text { Knapweed } \\
\text { Utilized } \\
\text { (kg/ha) }\end{array}$ & $\begin{array}{c}\text { Total } \\
\text { Herbage } \\
\text { Utilized } \\
(\mathrm{kg} / \mathrm{ha})\end{array}$ & $\begin{array}{c}\text { Stocking } \\
\text { Rate } \\
\text { (ha/AUM) }\end{array}$ & $\begin{array}{l}\text { Change in } \\
\text { Herbage } \\
\text { Utlized } \\
\text { (kg) }\end{array}$ & $\begin{array}{c}\text { Present } \\
\text { Value of } \\
\text { Loss }{ }^{1} \\
\text { (\$/ha) }\end{array}$ \\
\hline Year 1 & 111 & 79 & 16 & 202 & .60 & 2 & .02 \\
\hline Year 2 & 122 & 93 & 19 & 199 & .61 & 5 & .05 \\
\hline Year 3 & 135 & 108 & 22 & 196 & .62 & 8 & .07 \\
\hline Year 7 & 197 & 139 & 28 & 190 & .64 & 14 & .10 \\
\hline Year 8 & 217 & 143 & 29 & 189 & .64 & 15 & .11 \\
\hline Year 9 & 239 & 149 & 30 & 188 & .64 & 16 & .11 \\
\hline Year 10 & 263 & 155 & 31 & 187 & .65 & 17 & .11 \\
\hline Year 11 & 289 & 163 & 33 & 185 & .65 & 19 & .12 \\
\hline Year 12 & 318 & 173 & 35 & 183 & .66 & 21 & .12 \\
\hline Year 13 & 349 & 184 & 37 & 181 & .67 & 23 & .13 \\
\hline Year 18 & 405 & 256 & 51 & 167 & .73 & 38 & .17 \\
\hline Year 19 & 405 & 274 & 55 & 163 & .74 & 41 & .18 \\
\hline Year 20 & 405 & 293 & 59 & 159 & .76 & 45 & .18 \\
\hline \multicolumn{7}{|c|}{ Total } & $\$ 2.38$ \\
\hline
\end{tabular}

'Economic loss (\$/ha) is prorated over entire management unit.

thus long-term plant succession was not enhanced.

Economic impact of the no action strategy was estimated by allowing spotted knapweed to spread onto uninfested areas. Value of the forage displaced by the invading knapweed was calculated (Eq. 9; Table 1). Sensitivity analyses were used to assess the effects of site productivity, size of initial spotted knapweed infestation, value of AUMs, rate of spread, and knapweed utilization on economic feasibility of treatment.

\section{Model Assumptions and Limitations}

This analysis assumed that spotted knapweed control strategies were applied to rangeland formerly dominated by native bunchgrasses, such as bluebunch wheatgrass (Pseudoroegneria spicata) and rough fescue (Festuca scabrella). Large increases in native grass production occur during the first growing season following picloram treatment. By the third year, total herbage produced on infested areas approximates the total production on uninfested areas of the site. This level of production is maintained by proper grazing management and the periodic use of herbicides.

We did not separate out the effect of grazing intensity, grazing frequency, type of animal grazed, nor season of grazing on the expected forage response from treatment. However, knapweed reinvasion following herbicide treatment occurs more rapidly on sites dominated by lower-successional species or under grazing management that lowers the competitiveness of the native plants (C. Lacey, pers. comm.). Residual effectiveness of picloram treatments is influenced by clay and organic matter content of soils. Shallow gravelly sites require re-treatment more frequently than higher producing sites (Table 2).

\section{Results}

Present value of AUMs of $\$ 2.38$ / ha was lost due to the no action alternative (Table 3). By not treating the initial infestation, spotted knapweed had spread over the entire management unit by year 15 . However, knapweed production $(\mathrm{kg} / \mathrm{ha})$ was still increasing. Because of the increased knapweed, grazing capacity declined from .59 to .76 ha/AUM (Table 3). A total annual loss in current after-tax dollars of $\$ 964$ occurred.
After-tax present value of added AUMs obtained through the spotted knapweed eradication program was $\$ 3.41 /$ ha, which exceeded the present value of after-tax treatment costs, $\$ 1.99 /$ ha (Table 4). Thus knapweed control was economically feasible. The knapweed infestations were re-treated in years $0,3,6,9,12,15$, and 18. Carrying capacity was maintained at .56 ha/AUM (Table 4). Rather than calculating optimal treatment strategies (Ethridge et al. 1987), this treatment focused on the elimination of viable seeds. Viable seeds were assumed to have been eliminated by year 20 .

\section{Range Site Simulations}

Follow-up herbicide treatments to suppress spotted knapweed seedlings increased the cost of eradication on the low-producing site relative to the high-producing site (Table 5). Productivity differences between the 2 sites resulted in a higher forage response on the high-producing site. Thus, knapweed treatment was more profitable on the high-producing site (Table 5).

After-tax benefits exceeded after-tax costs for 3 of the 4 situations on the high producing site (Table 5). For the less productive site, costs exceeded benefits for each of the control strategies (Table 5). Thus, spotted knapweed control should be emphasized on high-producing rather than on low-producing sites.

\section{Forage Price Simulations}

Spotted knapweed eradication became more feasible as AUMs increased in value (Table 6). Present value of added AUMs with treatment exceeded present value of costs on the high-producing site $\$ .05$ and $\$ 2.78$ when AUMs were valued at $\$ 6$ and $\$ 14$, respectively.

Treatment became feasible on the low-producing site when AUMs were valued at \$14. Although cost of treatment is not altered, benefits are directly affected as the value of AUMs varies. Knapweed control becomes more cost-effective on low-producing sites when the value of forage increases.

\section{Rate of Spotted Knapweed Spread Simulations}

Economic losses increase geometrically with the rate of spotted knapweed spread (Table 7). Thus, measures to prevent weeds from 
Table 4. Summary of spotted knapweed eradication, given the specified parameters, of a high-producing site.

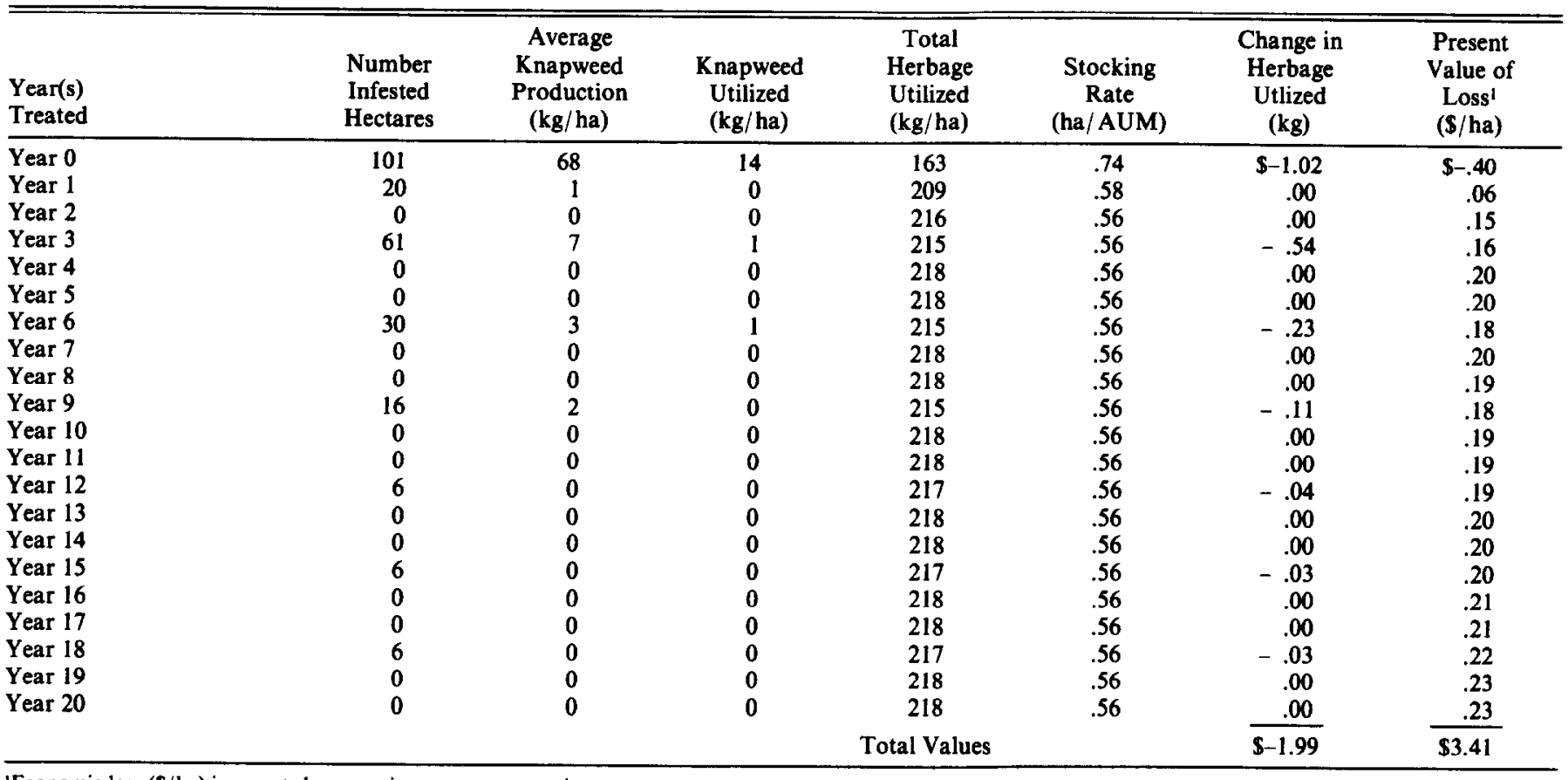

'Economic loss $(\mathrm{S} / \mathrm{ha})$ is prorated over entire management unit.

Table 5. Net present value of after-tax costs and benefits of spotted knapweed treatment calculated for 2 range sites, 2 control strategies (each with 2 levels of initial infestation), and prorated over the management unit. ${ }^{1}$

\begin{tabular}{|c|c|c|c|c|}
\hline \multirow{3}{*}{$\begin{array}{l}\text { Control } \\
\text { Strategy and } \\
\text { Initial } \\
\text { Infestation }\end{array}$} & \multicolumn{4}{|c|}{ Site $^{2}$} \\
\hline & \multicolumn{2}{|c|}{ High-producing } & \multicolumn{2}{|c|}{ Low-producing } \\
\hline & $\begin{array}{l}\text { Cost } \\
(\$ / h a)\end{array}$ & $\begin{array}{l}\text { Benefit } \\
(\$ / \text { ha })\end{array}$ & $\begin{array}{l}\text { Cost } \\
(\$ / h a)\end{array}$ & $\begin{array}{l}\text { Benefit } \\
(\$ / \text { ha })\end{array}$ \\
\hline $\begin{array}{l}\text { Complete Control } \\
\text { (100\% of ha) }\end{array}$ & -7.89 & +10.92 & -10.77 & +4.59 \\
\hline $\begin{array}{l}\text { Complete Control } \\
\text { ( } 50 \% \text { of ha) }\end{array}$ & -3.94 & +6.87 & -5.38 & +3.53 \\
\hline $\begin{array}{l}\text { Containment } \\
\text { ( } 25 \% \text { of ha) }\end{array}$ & -1.52 & +1.60 & -1.52 & +1.25 \\
\hline $\begin{array}{l}\text { Containment } \\
\text { ( } 50 \% \text { of ha) }\end{array}$ & -3.03 & +2.43 & -3.03 & +1.73 \\
\hline
\end{tabular}

$120 \%$ of knapweed utilized as forage; AUM valued at $\$ 10$.

${ }^{2}$ Current and potential productivity were 544 and 680 , and 272 and $318 \mathrm{~kg} / \mathrm{ha}$ for the high- and low-producing sites, respectively.

Table 6. Net present value of after-tax costs and benefits of eradicating knapweed calculated for 2 range sites, (each with 5 alternative AUM values), and prorated over the management unit'.

\begin{tabular}{|c|c|c|c|c|}
\hline \multirow{3}{*}{$\begin{array}{c}\text { Value of AUM } \\
\$\end{array}$} & \multicolumn{4}{|c|}{ Site $^{2}$} \\
\hline & \multicolumn{2}{|c|}{ High-producing } & \multicolumn{2}{|c|}{ Low-producing } \\
\hline & $\begin{array}{l}\text { Cost } \\
(\$ / \text { ha })\end{array}$ & $\begin{array}{l}\text { Benefit } \\
\text { (\$/ha) }\end{array}$ & $\begin{array}{c}\text { Cost } \\
(\mathbf{S} / \mathrm{ha})\end{array}$ & $\begin{array}{l}\text { Benefit } \\
\text { (\$/ha) }\end{array}$ \\
\hline 6 & -1.99 & +2.04 & -2.69 & +1.27 \\
\hline 8 & -1.99 & +2.93 & -2.69 & +1.69 \\
\hline 10 & -1.99 & +3.41 & -2.69 & +2.13 \\
\hline 12 & -1.99 & +4.09 & -2.69 & +2.54 \\
\hline 14 & -1.99 & +4.77 & -2.69 & +2.96 \\
\hline
\end{tabular}

$125 \%$ of hectares initially infested; complete control strategy; $20 \%$ of knapweed utilized as forage.

${ }^{2}$ Current and potential productivity were 544 and 680 , and 272 and $318 \mathrm{~kg} / \mathrm{ha}$ for the high- and low-producing sites, respectively. spreading onto previously uninfested range are important (Table 7).

Treatment of spotted knapweed was economically feasible on high producing sites when knapweed was spreading to new areas at a rate of $5 \%$ and replacing forage on infested hectares at a rate of $5 \%$. The economic feasibility of treatment improved as the rate of spread increased. However, after-tax costs exceeded after-tax benefits on low-producing sites at the 5, 10, and $15 \%$ rates of spread (Table 7).

\section{Livestock Use of Spotted Knapweed Simulations}

Economic benefits from spotted knapweed control change as animal diets change. Herbicide control is more feasible when livestock are utilizing little or no knapweed (Table 8). On a highproducing site, after-tax costs (\$1.99) were higher than after-tax benefits ( $\$ 1.39$ ) when $30 \%$ of the knapweed was used. When $25 \%$ or less of the knapweed on a high-producing site was utilized as forage, after-tax benefits exceeded after-tax costs.

After-tax costs exceeded after-tax benefits on low-producing sites when $30 \%$ of the knapweed was used. Treatment on low-

Table 7. Net present value of after-tax costs and benefits of spotted knapweed eradication calculated for 3 alternative rates of knapweed spread and forage replacement, on two range sites, and prorated over the management unit'.

\begin{tabular}{|c|c|c|c|c|}
\hline \multirow{3}{*}{$\begin{array}{l}\text { Rates of Knapweed } \\
\text { Spread \& Forage } \\
\text { Displacement } \\
\text { (Percent) }\end{array}$} & \multicolumn{4}{|c|}{ Site $^{2}$} \\
\hline & \multicolumn{2}{|c|}{ High-producing } & \multicolumn{2}{|c|}{ Low-producing } \\
\hline & $\begin{array}{c}\text { Cost } \\
(\$ / \text { ha })\end{array}$ & $\begin{array}{c}\text { Benefit } \\
(\$ / \text { ha })\end{array}$ & $\begin{array}{c}\text { Cost } \\
\text { (\$/ha) }\end{array}$ & $\begin{array}{l}\text { Benefit } \\
\text { (\$/ha) }\end{array}$ \\
\hline $\begin{array}{r}5 \text { and } 5 \\
10 \text { and } 10 \\
15 \text { and } 15\end{array}$ & $\begin{array}{l}-1.99 \\
-1.99 \\
-1.99\end{array}$ & $\begin{array}{l}+2.19 \\
+2.99 \\
+3.90\end{array}$ & $\begin{array}{l}-2.69 \\
-2.69 \\
-2.69\end{array}$ & $\begin{array}{l}+1.17 \\
+1.83 \\
+2.55\end{array}$ \\
\hline
\end{tabular}

$125 \%$ of hectares initially infested; complete control strategy; $20 \%$ of knapweed utilized as forage; AUM valued at $\$ 10$.

${ }^{2}$ Current and potential productivity were 544 and 680 , and 272 and $318 \mathrm{~kg} /$ ha for the high- and low-producing sites, respectively. 
Table 8. Net present value of after-tax costs and benefits of spotted knapweed eradication calculated for 6 alternative rates of utilization of spotted knapweed on 2 range sites, and prorated over the management unit'.

\begin{tabular}{|c|c|c|c|c|}
\hline \multirow{3}{*}{$\begin{array}{l}\text { \% Utilization } \\
\text { (Percent) }\end{array}$} & \multicolumn{4}{|c|}{ Site $^{2}$} \\
\hline & \multicolumn{2}{|c|}{ High-producing } & \multicolumn{2}{|c|}{ Low-producing } \\
\hline & $\begin{array}{c}\text { Cost } \\
(\$ / \text { ha })\end{array}$ & $\begin{array}{l}\text { Benefit } \\
(\$ / \text { ha })\end{array}$ & $\begin{array}{c}\text { Cost } \\
(\mathbf{S} / \text { ha })\end{array}$ & $\begin{array}{c}\text { Benefit } \\
(\$ / \text { ha })\end{array}$ \\
\hline $\begin{array}{r}5 \\
10 \\
15 \\
20 \\
25 \\
30\end{array}$ & $\begin{array}{l}-1.99 \\
-1.99 \\
-1.99 \\
-1.99 \\
-1.99 \\
-1.99\end{array}$ & $\begin{array}{r}+38.55 \\
+32.73 \\
+26.92 \\
+3.41 \\
+2.40 \\
+1.39\end{array}$ & $\begin{array}{l}-2.69 \\
-2.69 \\
-2.69 \\
-2.69 \\
-2.69 \\
-2.69\end{array}$ & $\begin{array}{l}+3.94 \\
+3.33 \\
+2.72 \\
+2.11 \\
+1.51 \\
+.89\end{array}$ \\
\hline
\end{tabular}

$125 \%$ of hectares initially infested; complete control strategy; AUM valued at $\$ 10$. ${ }^{2}$ Current and potential productivity were 544 and 680 , and 272 and $318 \mathrm{~kg} /$ ha for the high- and low-producing sites, respectively

producing sites was not economically feasible if more than $15 \%$ of the knapweed was being utilized as forage (Table 8).

\section{Management Implications}

A satisfactory understanding of the relation between economic and biologic variables was assumed in developing our model. Under the assumed conditions, the economic feasibility of spotted knapweed control varied with environment and economic variables. After-tax value of additional AUMs from treatment generally exceeded after-tax costs on high-producing sites. On lowproducing sites, the combination of higher treatment costs and lower herbage response limited the economic feasibility of using picloram to treat knapweed.

Economic returns increased as the value of forage increased, and with an increased rate of knapweed spread. In contrast, eradication was less cost-effective on lower-producing sites, and when livestock increased their use of knapweed as forage.

Further research regarding the ecological relationship of spotted knapweed on rangelands is needed. More information on rate of spotted knapweed spread, herbage response to treatment, the effect of grazing management on the life of the herbicide treatment, and livestock use of the weed will improve the ability of landowners to make correct economic decisions.

\section{Literature Cited}

Bawtree, A., and A. McLean. 1977. Rate of spread, potential range, losses and changes in pasture composition from diffuse and spotted knapweed in British Columbia. The Knapweed Sympos. Proc., Ministry of Agr., Victoria, B.C. Canada, Kamloops, British Columbia, p. 286.

Bedunah, D. 1989. Grass response following spotted knapweed control. Techline. Dow Chemical, U.S.A. January.

Bucher, R.F. 1984. The potential cost of spotted knapweed to Montana range users. Ext. Bull. 1316, Montana Coop. Ext. Serv. Dec. 1984.

Chicoine, Timothy Kevin. 1984. Spotted knapweed control, seed longevity and migration in Montana. MS thesis, Montana State Univ.

Davis, E.S., and P.K. Fay. 1989. The longevity of spotted knapweed seed in Montana. p. 67-72. In: Knapweed Sympos. Proc., Plant Soil Sci. Dept., and Ext. Serv., Montana State Univ., EB. 45. 1989.

Ethridge, D.E., B.E. Dahl, and R.E. Sosebee. 1984. Economic evaluation of chemical mesquite control using 2,4,5-T. J. Range Manage. 37:152-156.

Ethridge, D.E., R.D. Pettit, R.G. Sudderth, and A.L. Stoecker. 1987a. Optimal economic timing of range improvement alternatives; southern high plains. J. Range Manage. 40:555-559.

Ethridge, D.E., R.D. Pettit, T.J. Neal, and V.E. Jones. 1987b. Economic returns from treating sand shinnery oak with tebuthiuron in West Texas. J. Range Manage. 40:346-348.

Jenson, E.A. 1984. Data requirements for economic evaluations of a knapweed containment program. In: Knapweed Sympos. Proc., Plant \& Soil Sci. Dept. and Coop. Ext. Serv., Montana State Univ. Bull. 1315. p. 27-36.

Lacey, C. 1985. A weed education program, and the biology and control of spotted knapweed (Centaurea maculosa Lam.) in Montana. Master's Thesis, Montana State Univ., Bozeman, Mont.

Lacey, C.A., J.R. Lacey, T.K. Chicoine, P.K. Fay, and R.A. French. 1986. Controlling knapweed on Montana rangeland. Ext. Serv., Montana State Univ., Cir. 311.

Lacey, C. 1987. Report on noxious range weeds. Proc. of Montana Weed Control Annual Meeting.

Lacey, J.R. 1983. A complete takeover by knapweed in 2001? Montana Farmer-Stockman, July 7, 1983:32-34.

Lacey, J.R., C.B. Marlow, and J.R. Lane. 1989. Influence of spotted knapweed (Centaurea maculosa) on surface runoff and sediment yield. Weed Tech. 3:627-631. 